\title{
EFFECT OF USING METALLIC AND NON METALLIC - FIBER AND RIB GEOMETRY OF STEEL BARS ON BOND STRENGTH FOR HIGH STRENGTH CONCRETE (H. S. C.)
}

\author{
Aly Abdel-Zaher ELsayed; Hosny M. Soghair, Mohamed \\ M. Rashwan; and \\ Civil Engineering Department, Faculty of Engineering, Assuit University \\ Assiut, Egypt.
}

Ali Mohamed Abdallah Abou-Zied

Engineer in the general Authority of Educational Buildings Sohag, Egypt (Ph.D Student)

(Received December 8, 2009 Accepted May 21, 2011)

\begin{abstract}
The need of high strength concrete (H.S. C.) is increasing in the recent years. This material becomes necessary, but it is brittle. So, metallic fibers are used to enhance composite properties of (H.S. C.).The enhanced properties include tensile strength, compressive strength, elastic modulus, crack resistance, crack control, durability, fatigue life, resistance to impact and abrasion, shrinkage, expansion, thermal characteristics, and fire resistance of concrete. There is little information in the available literature about the bond characteristics for the different forms of rib geometry of the deformed bars on the strength between steel and high-strength fiber-reinforced concrete for different relative rib areas and fibers types .

The main objective of this research is to study the effect of using Metallic and Non Metallic- Fiber and rib geometry of steel bars on bond strength for high strength concrete (H. S. C.). Also Pattern of cracks, final mode of failure and deformational characteristics (direct slip for pull-out) were investigated.
\end{abstract}

\section{INTRODUCTION}

Nowadays, a wide range of engineering materials incorporate fibers to enhance composite properties. The enhanced properties include tensile strength, compressive strength, elastic modulus, crack resistance, crack control, durability, fatigue life, resistance to impact and abrasion, shrinkage, expansion, thermal characteristics, and fire resistance.

Experimental trials and patents involving the use of discontinuous steel reinforcing elements such as nails, wire segments, and metal chips to improve the properties of concrete date from 1910 by Naaman ${ }^{(1)}$. During the early 1960s in the United States, the first major investigation was made to evaluate the potential of steel fibers as a reinforcement for concrete by Romualdi $(1963)^{(2)}$. Since then, a substantial amount of research, development, experimentation, and industrial application of steel fiber reinforced concrete has occurred. M. H. Harajli and M. E. Mabsout $(2002)^{(3)}$ have studied the effect of fibers on the bond strength of deformed bars embedded in concrete. They have reported that the use of fiber reinforcement significantly increases 
the development/splice strength and considerably enhances the ductility of bond failure. The increase in bond strength acquired using steel fibers may reach levels substantially larger than the maximum limit stipulated in the ACI building code for ordinary transverse reinforcement.

High strength concrete (H..S.C.) with metallic fiber has been used worldwide with and without conventional reinforcement in many field applications. These include bridge deck overlays, floor slabs, pavements and pavement overlays, refractories, hydraulic structures, thin shells, rock slope stabilization, mine tunnel linings and many precast products. The guide for specifying, proportioning, mixing, placing, and finishing steel fiber-reinforced concrete is available from the ACI Committee 544 $[1993]^{(4)}$. The addition of steel fibers is used to improve most of the mechanical properties of concrete, namely, its static and dynamic tensile strength, energy absorption, toughness and fatigue resistance. Hence proper utilization of steel fiberreinforced concrete depends on the skill of the engineer in taking advantage of its improved characteristics under a given loading for a given application and the cost effectiveness of the fiber addition.

Bond strength for smooth bars depends upon adhesion and friction between steel bar and concrete ; Park \& Pauly.(1975) ${ }^{(5)}$ and Rehm.(1979) ${ }^{(6)}$. However, for deformed bars bond capacity increases because of the interlocking of the ribs with the surrounding concrete .

Pull-out specimens with high strength concrete studied by Sogh.etall.(2005) ${ }^{(7)}$. .They concoluded that four types of bond failures are typical as follows. The first is a direct pull-out of the bar. The second type of failure is a splitting and explosive of the concrete cover or confinement is insufficient to obtain a pull-out failure. The third type of failure is a shear failure in concrete along the lugs of the bar. The fourth type of failure is a fracture failure of the bar outside specimens. For small relative rib areas $\left(\propto_{\mathrm{sb}}<0.065\right)$ and smooth bars $\left(\propto_{\mathrm{sb}}=0.000\right)$, the failure is ductile but for medium and high relative rib areas $\left(\propto_{\mathrm{sb}} \geq 0.065\right)$, the failure is more brittle.

Rehm.(1979) ${ }^{(6)}$, Soretz and Holzenbein.(1980) ${ }^{(8)}$ showed that the influence of the deformation pattern of bar on the local bond stress-slip behavior can reasonably be described as a function of the relative rib area $\left(\boldsymbol{\alpha}_{\mathbf{s b}}\right)$ for pull-out speciments with normal strength concrete strength(NSC).The definition of the relative rib area $\left(\boldsymbol{\alpha}_{\mathbf{s b}}\right)$ is described by Rehm as (ratio of projected rib area normal to bar axis to the product of the nominal bar perimeter and the center-to-center rib spacing).

The effect of rib geometry $\left(\boldsymbol{\alpha}_{\mathbf{s b}}\right)$ for steel reinforcement on bond of normal strength concrete (N.S.C.) was studied by Aly et all.(2001) $)^{(9)}$ and Ali M.A.(2000) $)^{(10)}$ who found that the bond strength $\left(\mathbf{f}_{\mathrm{bu}}\right)$ increased by increasing the relative rib area $\left(\alpha_{\mathrm{sb}}\right)$ for unconfined specimens. The relationship between the ultimate bond strength $\left(f_{b u}\right)$ and the relative rib area can be estimated by using following equation:

$$
f_{\text {bu }}=215\left(\alpha_{s b}\right)^{0.264}
$$

for $\mathrm{f}_{\mathrm{c}}=300 \mathrm{~kg} \mid \mathrm{cm}^{2}, \mathrm{~L}_{\mathrm{b}}=5 \mathrm{~d}_{\mathrm{b}},\left(\alpha_{\mathrm{sb}}\right)>0.00$

But for high-performance concrete (H.P.C.) studied by. Sogh..et all.(2005) ${ }^{(7)}$.They found that the relationship between the ultimate bond strength $\left(\mathbf{f}_{\mathrm{bu}}\right)$ local bond and the relative rib areas $\left(\propto_{s b}\right)$ and the concrete compressive strength $\left(f_{c}\right)$ can be estimated as : 


$$
\begin{aligned}
& \left.\mathbf{f}_{\mathrm{bu}}=3.15 \sqrt{ } \mathbf{f}_{\mathrm{c}} \quad \mathrm{kg} / \mathrm{cm}^{2} \quad \text { for smooth bars }{ }^{(} \boldsymbol{\alpha}_{\mathrm{sb}}\right) \ldots \ldots \ldots \ldots \\
& \mathbf{f}_{\mathrm{bu}}=\left(\mathbf{5}+30.5\left(\boldsymbol{\alpha}_{\mathrm{sb}}\right) \sqrt{ } \mathbf{f}_{\mathrm{c}} \mathrm{kg} / \mathrm{cm}^{2} \quad \text { for ribbed bars . }\left(\boldsymbol{\alpha}_{\mathrm{sb}}\right) \ldots \ldots \ldots \ldots \ldots\right.
\end{aligned}
$$

They found also that for ribbed bars, the test results indicated that the average bond strength $\left(f_{b u}\right)$ at failure, normalized with respect to the square root of concrete compressive strength $\left(\sqrt{f_{c}}\right)$, decreases with increasing in the concrete compressive strength $\left(f_{c}\right)$ if a splitting failure occurred $\left(\alpha_{\mathrm{sb}} \geq 0.065\right)$, but it increases if a pull-out failure occurred $\left(\alpha_{\mathrm{sb}}<.0 .065\right)$.

\section{EXPERIMENTAL WORK}

Thirty Pull-out prismatic specimens were tested with steel diameters $16 \mathrm{~mm}$ and square cross section equal to $12 \times 12 \mathrm{~cm}$. The considered lengths for specimens were $15 \mathrm{~d}_{\mathrm{b}}$ for specimens, bonded parts for steel reinforcement used in the tested specimens were $5 d_{b}$ and concrete compressive strength of $\left(f_{c}\right)=900 \mathrm{~kg} / \mathrm{cm}^{2}$.. The study took into consideration the following parameters:

1- Rib geometry and its relative rib area $\left(\alpha_{\mathrm{sb}}\right)$ for steel reinforcement used in the tested specimens were $0.00,0.03,0.045,0.060,0.062,0.065,0.069,0.070$, $0.072,0.073,0.076,0.078,0.090,0.093$ and 0.10 .

2- Fiber types; four types of metallic and non- metallic fibers were used for all specimens (plain, harex steel, glass and polypropylene fibers).

The specimens were tested using a tensile testing machine of 30 ton capacity. The slip of the bar was measured using dial gauge with accuracy of $0.001 \mathrm{~mm}$. The load-slip relations for different parameters were proposed. The cracking process and mode of failure was obtained.

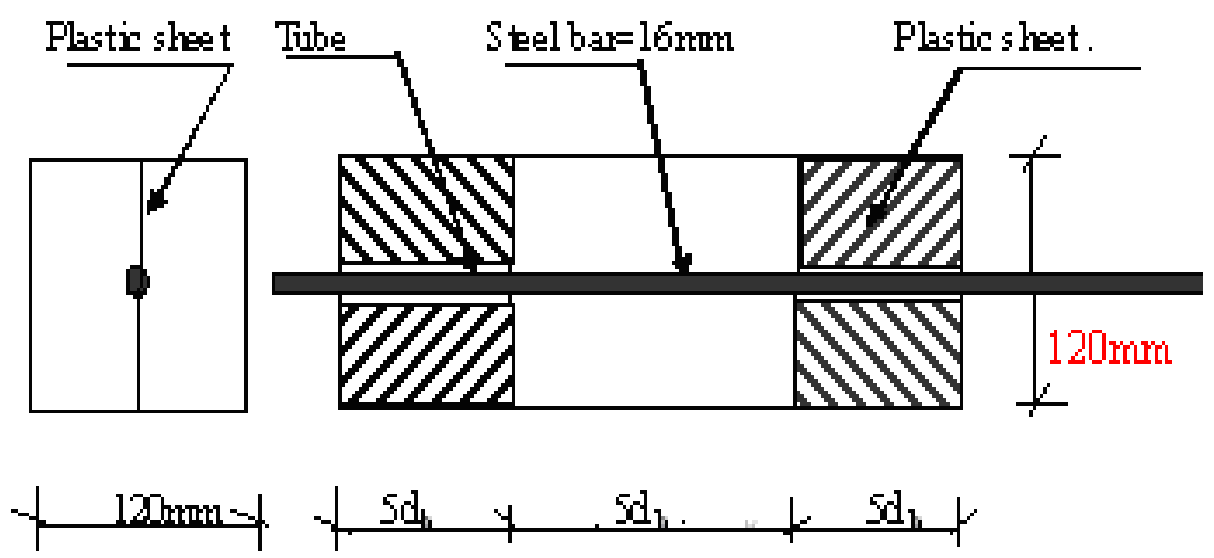

Fig. (1): Details of pull-out specimens

One concrete mix (HSC) was chosen from many experimental trials, to produce high strength concrete having a 28-days cubic compressive strength about 900 $\mathrm{kg} / \mathrm{cm}^{2}$. The mix proportions by weight are shown in Table (1).

Silica fume $110 \mathrm{~kg} / \mathrm{m}^{3}$ optimum dosage of silica fume with specific gravity 2.15 locally produced by ( The Egyptian Ferroalloys Co. ) in Edfo city. The used fine and Coarse aggregate have a specific gravity of 2.5 and 2.7 respectively. 
were used.

Super-plasticizer, with optimum dosage of $17.5 \mathrm{litre} / \mathrm{m}^{3}$ for concrete mix (HSC)

Table (1): Concrete Mix Components.

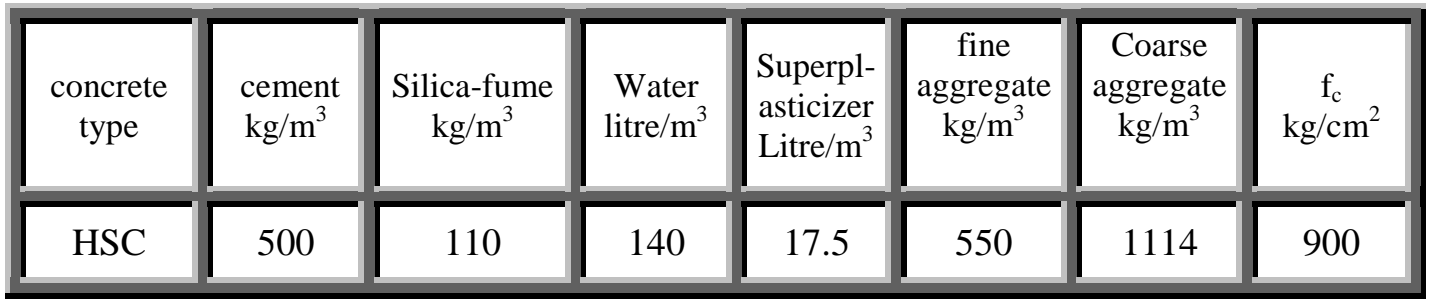

Table (2): Mechanical and Geometrical Properties of Plain and Deformed Bars.

\begin{tabular}{|c|c|c|c|c|c|c|}
\hline Series & $\begin{array}{c}\mathrm{d}_{\mathrm{b}} \\
(\mathrm{mm})\end{array}$ & $\begin{array}{c}\text { Specimens } \\
\text { Notation }\end{array}$ & $\begin{array}{c}\text { Relative } \\
\text { Rib Area } \\
\qquad\left(\alpha_{\mathrm{sb}}\right)\end{array}$ & $\begin{array}{c}\text { Yield } \\
\text { Strength (fy) } \\
\mathrm{kg} / \mathrm{cm}^{2}\left(\mathrm{f}_{\mathrm{y}}\right)\end{array}$ & $\begin{array}{c}\text { Ultimate } \\
\text { Strength } \\
\mathrm{kg} / \mathrm{cm}^{2}\left(\mathrm{f}_{\mathrm{u}}\right)\end{array}$ & $\begin{array}{c}\% \\
\text { Elongation }\end{array}$ \\
\hline \multirow{15}{*}{$\begin{array}{c}\text { From } \\
\text { CF1-15 } \\
\text { to } \\
\text { CF16-30 }\end{array}$} & \multirow{15}{*}{16} & $\mathrm{~S} \mathrm{~m}$ & 0.000 & 3100 & 4600 & 28.6 \\
\hline & & $\mathrm{Lxx}$ & 0.030 & 4600 & 6940 & 22.4 \\
\hline & & $\mathrm{BS}$ & 0.045 & 4360 & 6880 & 19.9 \\
\hline & & $\mathrm{EZ}$ & 0.060 & 4700 & 6990 & 20.3 \\
\hline & & $\mathrm{B} \backslash \mathrm{S}$ & 0.062 & 4600 & 6700 & 19.2 \\
\hline & & EZ1AL & 0.065 & 4500 & 6675 & 19.7 \\
\hline & & EZ-AL & 0.069 & 4600 & 6650 & 19.3 \\
\hline & & EZ.AL1 & 0.070 & 4750 & 6700 & 18.6 \\
\hline & & ARSL & 0.072 & 4600 & 6750 & 18.4 \\
\hline & & NS & 0.073 & 4400 & 6450 & 18.6 \\
\hline & & $\mathrm{TS}$ & 0.076 & 4450 & 6550 & 19.0 \\
\hline & & DK2 & 0.078 & 4550 & 6800 & 19.5 \\
\hline & & DK1 & 0.090 & 4450 & 6200 & 20.5 \\
\hline & & BS5 & 0.093 & 4300 & 6190 & 18.8 \\
\hline & & EZ.AL2 & 0.100 & 4750 & 6900 & 18.5 \\
\hline
\end{tabular}

Metallic and Non-metallic fibers were incorporated in this study. The metallic fiber used included two different types, i.e. plain and harex steel fibers. The nonmetallic fiber used in pullout specimens included two different types, i.e. glass and polypropylene fibers. Typical properties of various types of the metallic and nonmetallic fibers are given in Table (3). One fiber concentration was used in the specimens, this was $1.0 \%$ by volume of the total mix .The plain steel fiber (round steel fibers) were produced by cutting smooth high tensile steel wire of uniform cross section . 
Table (3): Typical Properties of Metallic and Non-Metallic Fibers.

\begin{tabular}{|c|c|c|c|c|c|c|}
\hline Type of fibers & $\begin{array}{c}\text { Diameter } \\
(\mu \mathrm{m})\end{array}$ & $\begin{array}{c}\text { Length } \\
(\mathrm{mm})\end{array}$ & $\begin{array}{c}\text { Density } \\
\left(\mathrm{gm} / \mathrm{cm}^{3}\right)\end{array}$ & $\begin{array}{c}\text { Tensile } \\
\text { Strength } \\
\mathrm{kg} / \mathrm{cm}^{2}\end{array}$ & $\begin{array}{c}\text { Young's } \\
\text { modulus } \\
\mathrm{kg} / \mathrm{cm}^{2}\end{array}$ & $\begin{array}{c}\text { Elongation } \\
(\%)\end{array}$ \\
\hline plain steel (P.S.F) & 500 & 50 & 7.8 & $0.6 * 10^{4}$ & $2 * 10^{6}$ & 20 \\
\hline $\begin{array}{c}\text { Harex steel } \\
\text { (H.S.F })\end{array}$ & 1000 & 32 & 7.8 & $2 * 10^{4}$ & $2 * 10^{6}$ & 3 \\
\hline Glass (Cem-Fil) & $2-20$ & 12 & 2.7 & $2.5 * 10^{4}$ & $8 * 10^{5}$ & 3.6 \\
\hline Polypropylene & $2-20$ & 18 & 0.91 & $0.5 * 10^{4}$ & $0.5 * 10^{5}$ & $8-10$ \\
\hline
\end{tabular}

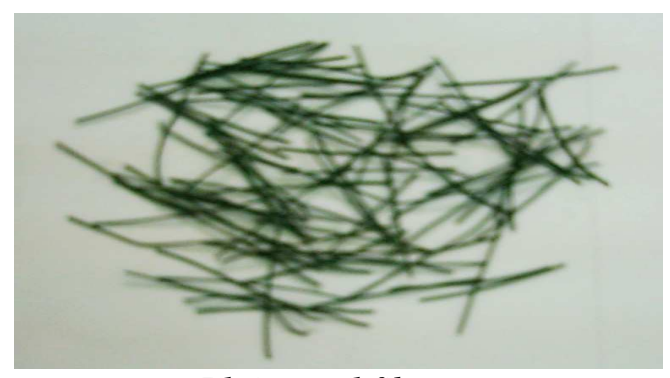

a-Plain steel fiber

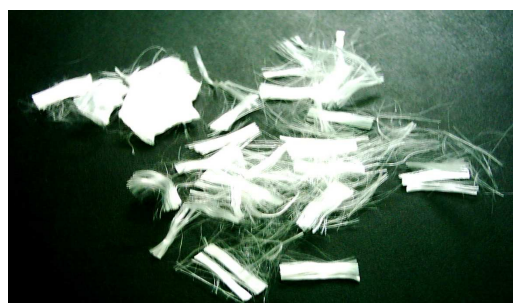

A-Glass Fibers

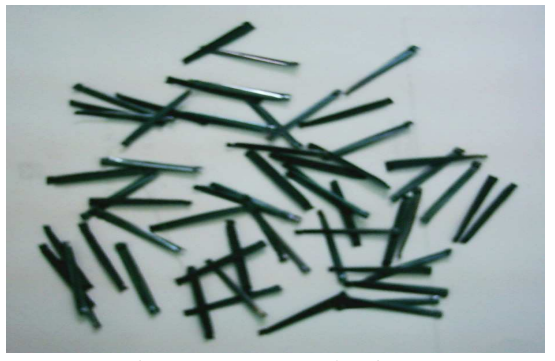

b-Harex steel fiber

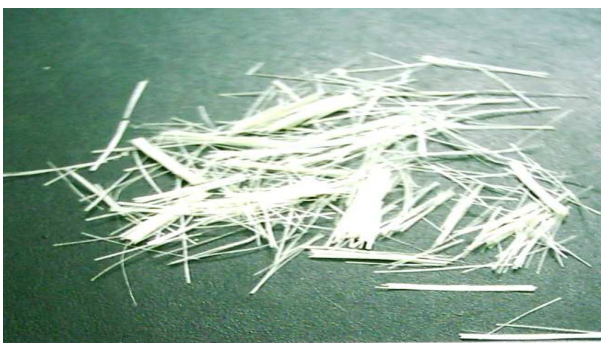

B-Polypropylene Fibers

Photo (1): Shape of Metallic and Non-Metallic fibers

\section{GENERAL BEHAVIOR AND MODE OF FAILURE}

Three types of failure can be distinguished according to the largest value of the shear, principal tensile, or fibers types or relative rib area $\left(\alpha_{\mathrm{sb}}\right)$ as follows: -

(1)-Pullout failure of the bar «Shear failure along the perimeter of

the bar» which occurs when ample confinement is provided to the bar resulting highest values of the tensile strength for (H.S.C.) and so the max shear strength is less than the max. .shear resistance (case of specimens with deformed bars having small relative rib area $\left(0.0 \leq \alpha_{\mathrm{sb}} \leq 0.05\right)$ for metallic fibers as shown in Fig. (2a). 
(2)-Tension Failure of prism, which occurs when just confinement is provided to the bar resulting critical values of the tensile strength for (H.S.C.) and so the max. .shear strength equal to the max.shear resistance (case of specimens with deformed bars having medium relative rib area $\left.\left(0.05<\alpha_{\mathrm{sb}} \leq 0.075\right)\right)$ as shown in Fig. (2b).

(3)- Splitting failure of concrete cover, which occurs when the cover is insufficient to obtain a pullout failure and the shear strength is high enough to avoid shear failure, but the principal tensile stress may exceed the tensile strength resulting the increase of bond between ribbed steel bars impeded in (HSC). (case of specimens with deformed bars having high relative rib area $\left(0.075<\alpha_{\mathrm{sb}} \leq 0.10\right)$ ), as shown in Fig. (2c).

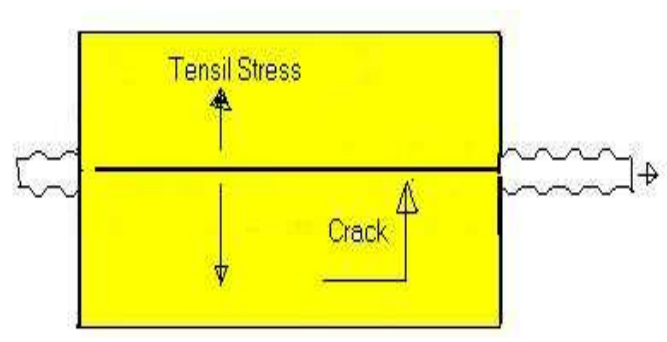

(a)-Case (No.1): )-Pull-out failure of the bar

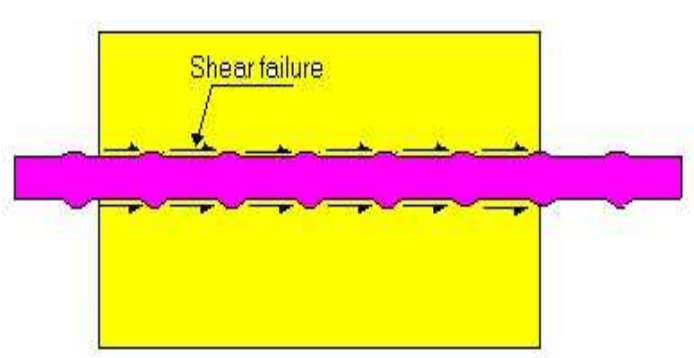

(b)-Case (No.2):Tensile failure of prism

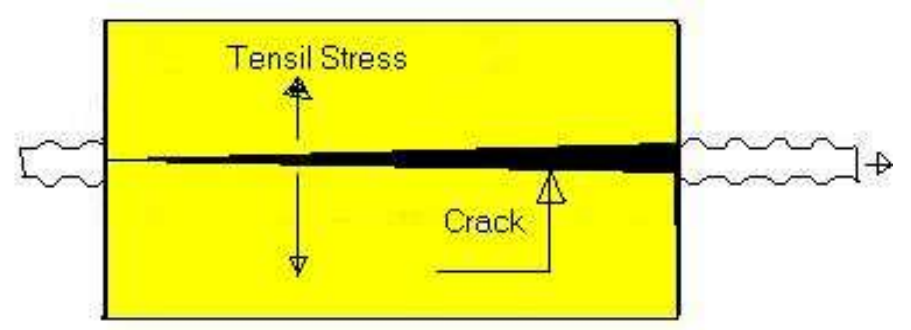

(c)-Case (No.3): Splitting failure of concrete cover

Fig. (2): Mode of bond failure

The use of metallic and non-metallic fibers enhanced the ductility of bond failure, while an explosive splitting of concrete type of failure occurs for specimens without fiber. The failure becomes tension failure of prism type or splitting failure type for specimens with fibers.

\section{TEST RESULTS}

The test results are summarized in Table (4) for specimens without fibers. Also Table (5) for specimens with Plain and Harex steel fibers. The ultimate bond strength, $\left(\mathrm{f}_{\mathrm{bu}}\right)$, was calculated by the relation

$$
\mathrm{f}_{\mathrm{bu}}=\mathrm{P}_{\mathrm{u}} / \mathrm{L}_{\mathrm{b}}\left(\pi \mathrm{d}_{\mathrm{b}}\right) \text {, }
$$

Where $P_{u}$ is the ultimate load, $L_{b}$ is the embedded length of bar and $d_{b}$ is the bar diameter. The effect of the various parameters on the load-slip characteristics will be discussed as follows. 


\section{Effect of relative rib area ( $\alpha \mathrm{sb})$}

The values of the applied load from pull-out test increased with the increase of the relative rib area $\left(\alpha_{\mathrm{Sb}}\right)$. Generally the shape of the load-slip curves of tested prismatic specimens for small relative rib area $\left(\alpha_{\mathrm{sb}}\right)$ differs from the shape of the load-slip curves of tested prismatic specimens for high relative rib area $\left(\alpha_{\mathrm{Sb}}\right)$. .Also with increasing the relative rib area of steel bar the failure of specimens was brittle and the stiffness of the load -slip relationship increased as shown in Figs. (3) and (4).

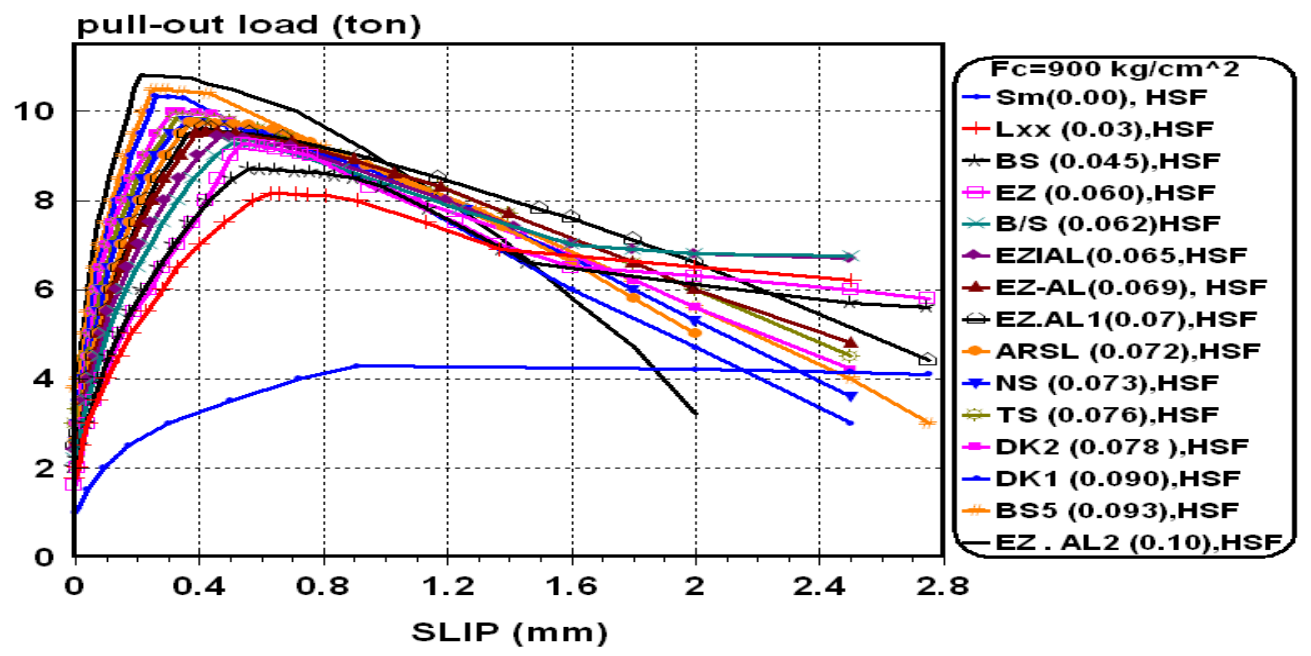

Fig. (3 ): Pull-out load -Slip relationship for tested specimens with different rib area $\left(\alpha_{\mathrm{Sb}}\right)$ and Harex steel fibers (H.S.F).

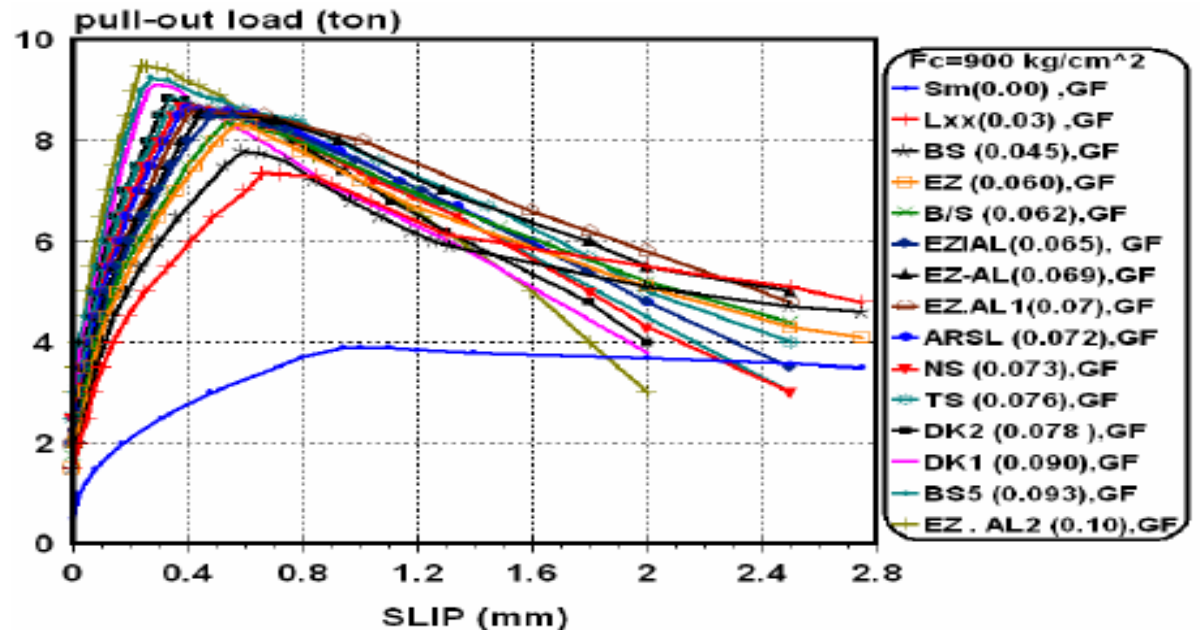

Fig. (4): Pull-out load-Slip relationship for tested specimens with different rib area $\left(\alpha_{\mathrm{Sb}}\right)$ and Glass fibers (G.F).

\section{Effect of fibers types}

The values of the applied load at all values of slip for prismatic specimens having metallic fibers were more than those values of prismatic specimens with non-metallic 
fibers. The values of the applied load at all values of slip for prismatic specimens having non-metallic fibers were more than that values of prismatic specimens without fibers for high strength concrete(H.S.C.). The splitting failure of specimens was more brittle for high strength concrete without fibers .But for high strength concrete with fibers the splitting failure of specimens was less brittle, as shown in figs. (5).

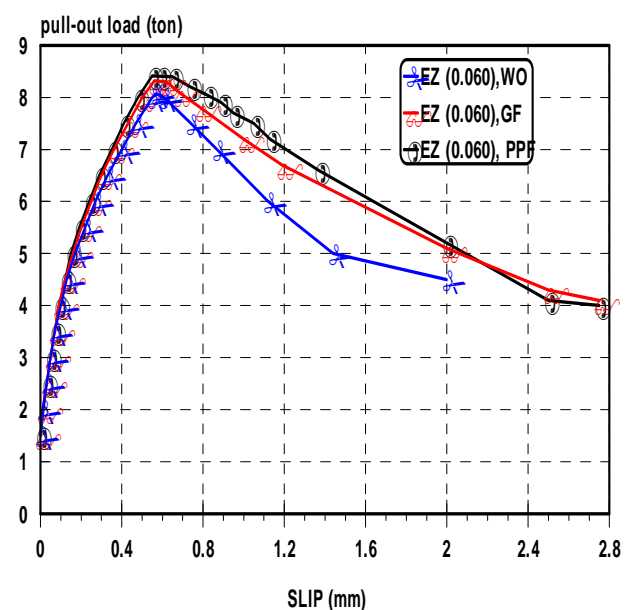

(a) - For bar $\left(E Z, \alpha_{\mathrm{sb}}=0.060\right.$,

\section{pull-out load (ton)}

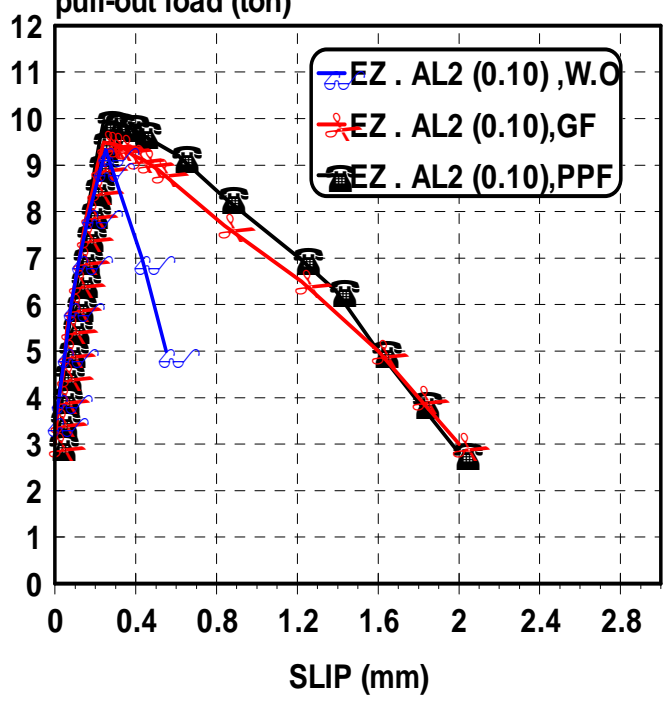

(c) - For bar (EZ.AL2, $\alpha \mathrm{sb}=0.10)$

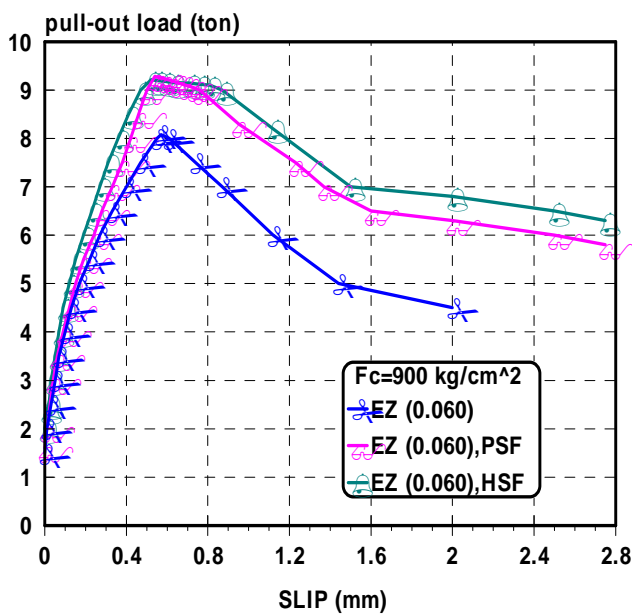

(b) - For bar $\left(E Z, \alpha_{\mathrm{sb}}=0.060\right.$, pull-out load (ton)

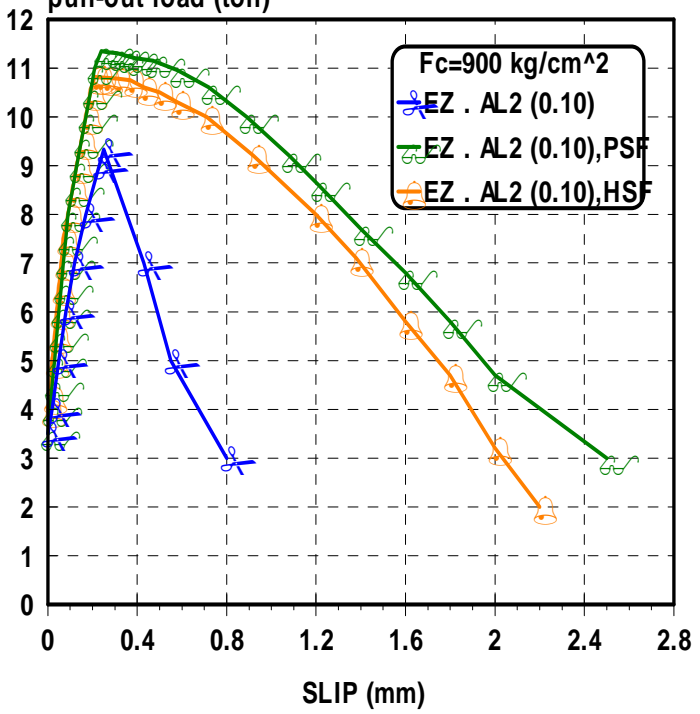

(d) - For bar (EZ.AL2, $\alpha \mathrm{sb}=0.10)$

Fig. (5 ):Pull-out load -Slip relationship for tested specimens without and with metallic fibers, 
Table (4): Values of the ultimate bond strength (fbu) for pull-out specimens without fibers, Sogh. et al. ${ }^{(7)}$.

\begin{tabular}{|c|c|c|c|}
\hline $\begin{array}{c}\text { Specimens } \\
\text { Notation }\end{array}$ & $\begin{array}{c}\text { Relative } \\
\text { Rib Area } \\
\left(\alpha_{\mathrm{sb}}\right)\end{array}$ & $\begin{array}{c}\text { Ultimate Bond } \\
\text { Strength } \\
\mathrm{f}_{\mathrm{bu}} \mathrm{kg} / \mathrm{cm}^{2}\end{array}$ & $\begin{array}{c}\text { Mode of Failure } \\
\text { (Failure Type) }\end{array}$ \\
\hline S m & 0.000 & 96.61 & Pull-out \\
\hline L xx & 0.030 & 179.5 & Pull-out \\
\hline BS & 0.045 & 190 & Pull-out \\
\hline EZ & 0.060 & 200.8 & Splitting \\
\hline B 1 S & 0.062 & 201.92 & Splitting \\
\hline EZ1AL & 0.065 & 204.81 & Splitting \\
\hline EZ-AL & 0.069 & 206.9 & Splitting and explosive \\
\hline EZ.AL1 & 0.070 & 208.39 & Splitting and explosive \\
\hline ARSL & 0.072 & 210.5 & Splitting and explosive \\
\hline NS & 0.073 & 211.3 & Splitting and explosive \\
\hline TS & 0.076 & 212.6 & Splitting and explosive \\
\hline DK2 & 0.078 & 215 & Splitting and explosive \\
\hline DK1 & 0.090 & 222 & Splitting and explosive \\
\hline BS5 & 0.093 & 224.9 & Splitting and explosive \\
\hline EZ.AL2 & 0.100 & 231.35 & Splitting and explosive \\
\hline
\end{tabular}


Table (5): Values of the Ultimate bond stress $\left(f_{b u}\right)$ for pull-out specimens

\begin{tabular}{|c|c|c|c|c|c|}
\hline Series & $\begin{array}{c}\text { Specimens } \\
\text { Notation }\end{array}$ & $\left(\alpha_{\mathrm{sb}}\right)$ & $\begin{array}{l}\text { Fiber } \\
\text { Types }\end{array}$ & $\begin{array}{c}\mathbf{f}_{\mathrm{bu}} \\
\mathrm{kg} / \mathrm{cm}^{2}\end{array}$ & Mode of Failure \\
\hline \multirow{15}{*}{ CF1-15 } & $\mathrm{S} \mathrm{m}$ & 0.000 & \multirow{15}{*}{$\begin{array}{c}\text { Plain } \\
\text { Steel } \\
\text { Fiber } \\
\text { (P.S.F) }\end{array}$} & 104.346 & Pull-out \\
\hline & $\mathrm{Lxx}$ & 0.030 & & 196.531 & Pull-out \\
\hline & $\mathrm{BS}$ & 0.045 & & 210.880 & Pull-out \\
\hline & EZ & 0.060 & & 230.775 & Pull-out \\
\hline & $\mathrm{B} \backslash \mathrm{S}$ & 0.062 & & 233.261 & Pull-out \\
\hline & EZ1AL & 0.065 & & 237.489 & Pull-out \\
\hline & EZ-AL & 0.069 & & 240.970 & Tension Failure of prism \\
\hline & $\overline{\text { EZ.AL1 }}$ & 0.070 & & 243.830 & Tension Failure of prism \\
\hline & ARSL & 0.072 & & 247.436 & Tension Failure of prism \\
\hline & NS & 0.073 & & 249.426 & Tension Failure of prism \\
\hline & TS & 0.076 & & 252.410 & Tension Failure of prism \\
\hline & DK2 & 0.078 & & 255.891 & Tension Failure of prism \\
\hline & DK1 & 0.090 & & 265.341 & Splitting \\
\hline & BS5 & 0.093 & & 269.320 & Splitting \\
\hline & EZ.AL2 & 0.100 & & 282.251 & Splitting \\
\hline \multirow{15}{*}{ CF16-30 } & $\mathrm{Sm}$ & 0.000 & \multirow{15}{*}{$\begin{array}{c}\text { Harex } \\
\text { Steel } \\
\text { Fiber } \\
\text { (H.S.F) }\end{array}$} & 106.285 & Pull-out \\
\hline & Lxx & 0.030 & & 202.823 & Pull-out \\
\hline & $\mathrm{BS}$ & 0.045 & & 216.600 & Pull-out \\
\hline & EZ & 0.060 & & 229.034 & Pull-out \\
\hline & $\mathrm{B} \backslash \mathrm{S}$ & 0.062 & & 230.526 & Pull-out failure \\
\hline & EZ1AL & 0.065 & & 234.256 & Pull-out failure \\
\hline & EZ-AL & 0.069 & & 237.247 & Tension Failure of prism \\
\hline & EZ.AL1 & 0.070 & & 239.232 & Tension Failure of prism \\
\hline & ARSL & 0.072 & & 242.214 & Tension Failure of prism \\
\hline & NS & 0.073 & & 243.457 & Splitting \\
\hline & $\mathrm{TS}$ & 0.076 & & 245.447 & Splitting \\
\hline & DK2 & 0.078 & & 248.555 & Splitting \\
\hline & $\overline{D K 1}$ & 0.090 & & 257.135 & Splitting \\
\hline & BS5 & 0.093 & & 260.865 & Splitting \\
\hline & EZ.AL2 & 0.100 & & 269.071 & Splitting \\
\hline
\end{tabular}


Table (6): Values of the Ultimate bond strength $\left(f_{b u}\right.$ ) for pull-out specimens with Glass fibers (G. F.) and polypropylene fibers ( P.P.F.).

\begin{tabular}{|c|c|c|c|c|}
\hline $\begin{array}{c}\text { Specimens } \\
\text { notation }\end{array}$ & $\left(\alpha_{\mathbf{s b}}\right)$ & Fiber Types & $\begin{array}{c}\left(\mathbf{f}_{\text {bu }}\right) \\
\mathrm{kg} / \mathrm{cm}^{2}\end{array}$ & Mode of failure \\
\hline $\mathrm{S} \mathrm{m}$ & 0.000 & \multirow{15}{*}{$\begin{array}{l}\text { Glass Fibers } \\
\text { (G.F.) }\end{array}$} & 96.98 & Pull-out \\
\hline $\mathrm{Lxx}$ & 0.030 & & 182.77 & Pull-out \\
\hline $\mathrm{BS}$ & 0.045 & & 193.72 & Pull-out \\
\hline $\mathrm{EZ}$ & 0.060 & & 206.90 & Tension Failure of prism \\
\hline$B \backslash S$ & 0.062 & & 207.89 & Tension Failure of prism \\
\hline EZ1AL & 0.065 & & 210.88 & Tension Failure of prism \\
\hline EZ-AL & 0.069 & & 211.87 & Splitting \\
\hline EZ.AL1 & 0.070 & & 213.61 & Splitting \\
\hline ARSL & 0.072 & & 215.11 & Splitting \\
\hline NS & 0.073 & & 216.35 & Splitting \\
\hline TS & 0.076 & & 217.59 & Splitting \\
\hline DK2 & 0.078 & & 219.83 & Splitting \\
\hline DK1 & 0.090 & & 226.79 & Splitting \\
\hline BS5 & 0.093 & & 229.78 & Splitting \\
\hline EZ.AL2 & 0.100 & & 235.99 & Splitting \\
\hline $\mathrm{S} \mathrm{m}$ & 0.000 & \multirow{15}{*}{$\begin{array}{c}\text { Polypropylene } \\
\text { Fibers } \\
\text { (P.P.F.) }\end{array}$} & 99.472 & Pull-out \\
\hline $\mathrm{Lxx}$ & 0.030 & & 185.764 & Pull-out \\
\hline $\mathrm{BS}$ & 0.045 & & 197.601 & Pull-out \\
\hline $\mathrm{EZ}$ & 0.060 & & 209.338 & Tension Failure of prism \\
\hline $\mathrm{B} \backslash \mathrm{S}$ & 0.062 & & 211.129 & Tension Failure of prism \\
\hline EZ1AL & 0.065 & & 214.610 & Tension Failure of prism \\
\hline EZ-AL & 0.069 & & 217.246 & Tension Failure of prism \\
\hline EZ.AL1 & 0.070 & & 219.335 & Tension Failure of prism \\
\hline ARSL & 0.072 & & 222.071 & Tension Failure of prism \\
\hline $\mathrm{NS}$ & 0.073 & & 223.563 & Splitting \\
\hline $\mathrm{TS}$ & 0.076 & & 225.304 & Splitting \\
\hline DK2 & 0.078 & & 227.293 & Splitting \\
\hline DK1 & 0.090 & & 236.494 & Splitting \\
\hline BS5 & 0.093 & & 239.976 & Splitting \\
\hline EZ.AL2 & 0.100 & & 247.436 & Splitting \\
\hline
\end{tabular}




\section{DISCUSSIONS OF RESULTS}

This item describes and interprets the analysis of the obtained test results of the (HSC) Pull-out specimens with metallic and non-metallic fibers. The analysis includes the relationship between the average values of the ultimate bond strength versus relative rib area of bars $\left(\alpha_{\mathrm{sb}}\right)$, and fibers types for pull-out specimens.

\section{Influence Of Relative Rib Area ( $\alpha$ sb )}

The average value of the ultimate bond strength $\left(f_{\text {bu }}\right)$ for pull-out prismatic specimens having high relative rib area $\left(\alpha_{s} \geq 0.06_{b}\right)$ for bars were higher than the corresponding value for pull-out specimens having low relative rib area $\left(\alpha_{\mathrm{sb}}<0.065\right)$ for bars as a result of decrease relative movement between the rib and concrete, .The average values of the ultimate bond strength. $\left(f_{\mathrm{bu}}\right)$ for pull-out prismatic specimens increase with the increase of the relative rib area $\left(\alpha_{\mathrm{sb}}\right)$.

It can be estimated using the equations:

$f_{b u}=157.0+730\left(\alpha_{s b}\right) \ldots \ldots$ for $\left(\alpha_{s b}\right)>0.0$, specimens without fibers

$\mathrm{f}_{\mathrm{bu}}=161.0+746\left(\alpha_{\mathrm{sb}}\right) \ldots \ldots$ for $\left(\alpha_{\mathrm{sb}}\right)>0.0$, specimens with glass fibers $(\mathrm{G} . \mathrm{F})$

$f_{b u}=157.6+887\left(\alpha_{s b}\right) \ldots .$. for $\left(\alpha_{s b}\right)>0.0$, specimens with polypropylene fibers (P.P.F) (7)

$\mathrm{f}_{\mathrm{bu}}=158.5+1218\left(\alpha_{\mathrm{sb}}\right) \ldots \ldots$ for $\left(\alpha_{\mathrm{sb}}>0.0\right)$, , specimens with plain steel fibers (P.S.F)...(8)

$f_{b u}=173.6+941.5\left(\alpha_{s b}\right) \ldots$ for $\left(\alpha_{s b}>0.0\right)$, , specimens with harex steel fibers(H.S.F ) ..(9)

as shown in Fig. ( 6 ) .

Equations $(5,6,7,8 \& 9)$ and the test results indicated that the increase of relative rib area $\left(\alpha_{\mathrm{sb}}\right)$ of steel bar increases the bond strength. The failure of specimens was brittle for high relative rib area $\left(\alpha_{\mathrm{sb}}\right)$. Ductile failure was achieved for small and medium relative rib area $\left(\alpha_{\mathrm{sb}}\right)$. The stiffness of the load-slip relationship the relative rib area $\left(\alpha_{\mathrm{sb}}\right)$ increases.
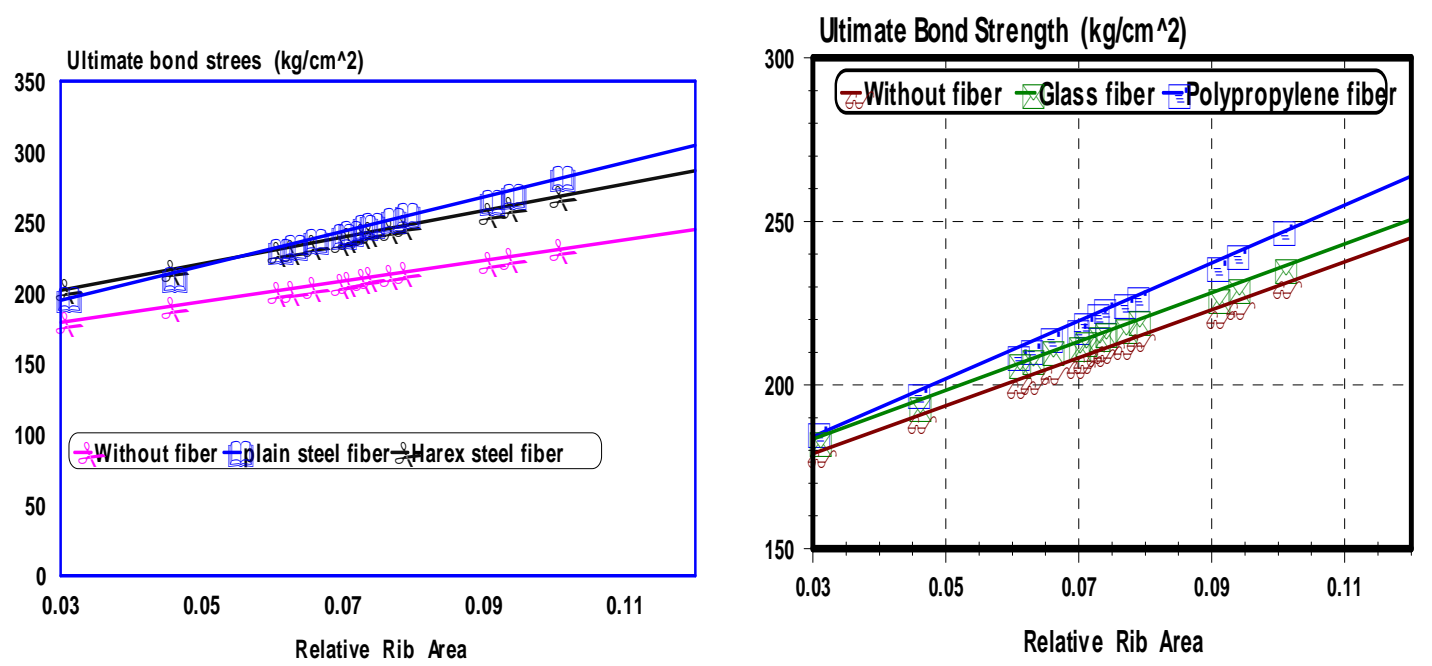

Fig. ( 6 ):Ultimate bond strength $\left(f_{b u}\right)$ versus relative rib area $\left(\alpha_{\mathrm{sb}}\right)$ for tested Specimens. 


\section{Influence Of fibers types}

The average value of the ultimate bond strength for pull-out prismatic specimens increases due to the addition of fibers for concrete due to decrease of the slip between concrete and steel bars, as shown in Fig. (7) .Fibers enhanced the ultimate bond strength and the bond behavior of deformed bars by arresting the bond and splitting cracks, and possibly by delaying the crushing of concrete between the lugs.

Adding (G.F .and P.P.F) to the specimens increased the ultimate bond strength $\left(\mathbf{f}_{\text {bu }}\right)$ by 3 and $7 \%$ respectively.Also adding plain and harex steel fibers (H.S.F) to the specimens increased the ultimate bond strength (fbu) by 22 and $17 \%$ respectively. The use of fibers enhanced the ductility of bond failure. Metallic fibers enhanced the bond strength more than non- metallic fibers.
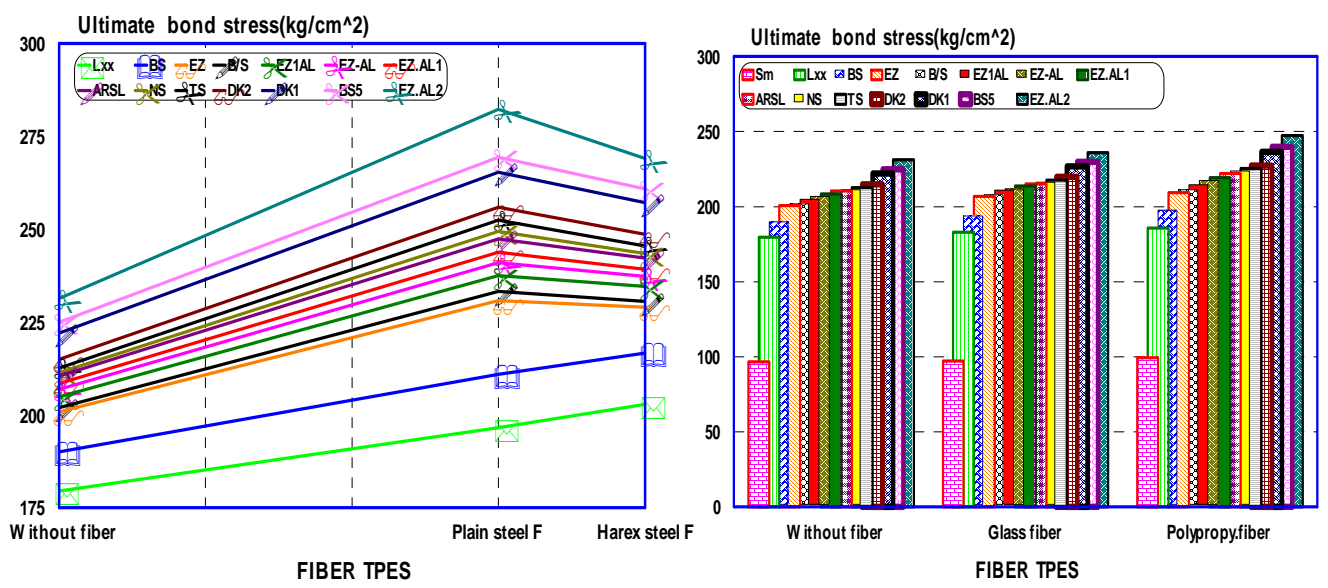

Fig. ( 7 ):Ultimate bond strength $\left(f_{b u}\right)$ versus fibers types for specimens

\section{SUMMARY AND CONCLUSIONS}

1- The modes of failure of high-strength concrete with fibers for pull-out specimens depend on the rib geometry $\left(\propto_{\mathrm{sb}}\right)$ for the steel bars and the fibers types.

2- Shear failure occurs along the perimeter of the bar for case of specimens with deformed bars having small relative rib areas $\left(\propto_{\mathrm{sb}}\right) \leq 0.05$ and for smooth bars $\left(\propto_{\mathrm{sb}}\right)=0.00$.

3- Tension failure of specimens occurs with deformed bars having medium relative rib area $.0 .05<\propto_{\mathrm{sb}} \leq 0.075$

4- Splitting failure of concrete cover takes place in case of specimens with deformed bars having high relative rib areas $\propto_{\mathrm{sb}}>0.075$

5- The modes of failures are affected by the presence of fiber types. Tension failure depends on fiber types.

6- The use of fibers enhanced the ductility of bond failure, the pull-out failure type obtained for specimens without or with fibers (plain or harex steel fibers).

7- The ultimate loads increased with the increase of relative rib area $\left(\alpha_{\mathrm{sb}}\right)$ and the type of fibers . 
8- The average value of the ultimate loads for specimens having metallic fibers were large than the corresponding value with non-metallic fibers.

9- The average value of the ultimate loads for specimens having high relative rib area $\left(\alpha_{\mathrm{sb}}\right) \geq 0.075$ were higher than the corresponding value for having medium relative rib area $0.05 \leq\left(\alpha_{\mathrm{sb}}\right) \leq 0.075$. Also the average value of the ultimate loads for specimens having medium relative rib area $0.05 \leq\left(\alpha_{\mathrm{sb}}\right) \leq 0.075$ were higher than the corresponding value for specimens having low relative rib area $\left(\alpha_{\mathrm{sb}}\right)<0.05$.

10 - The average values of the ultimate bond strength $\left(f_{b u}\right)$ for specimens with and without fiber increased with the increase of the relative rib area $\left(\alpha_{\mathrm{sb}}\right)$.

11- The average value of the ultimate bond strength $\left(f_{b u}\right)$ for specimens having fibers were higher than the corresponding values for specimens without fibers. Also the average value of the ultimate bond strength $\left(f_{b u}\right)$ for specimens having metallic fibers were higher than the corresponding values for specimens with nonmetallic fibers.

\section{REFERENCES}

1- Naaman, A. E., "Fiber Reinforcement for Concrete," Concrete International: Design and Construction, Vol. 7, No. 3, Mar. 1985, pp. 21-25.

2- Romualdi, J. P., and Batson, G.B.,"Mechanics of Crack Arrest in Concrete," J. Eng. Mech. Div., ASCE, Vol. 89, No. EM3, June 1963, pp. 147-168.

3- M. H. Harajli and M. E. Mabsout (2002)

4- ACI Committee 544 [1993]

5- R.Park and T.Pauly "Reinforced Concrete Structures "John Wiely , Sons, Chichester, London Toronto 1975.

6- Rehm,G, Eligehausen and Neubert, B.Erlauterung der Bewehrungsrichtlinien (Rationale for the detailing provisions of DIN 1045) Deutscher Ausschuss Fur Stahlbeton, Heft 300,1979.

7- Hosny M .Soghair; Mohamed M. Rashwaan; Aly Abdel-Zaher ELsayed and Ali M.Abdallah (2005) " Effect of rib geometry of steel bars on bond strength for high performance concrete" Bulletin of the faculty of engineering, Vol. 33, no. 5 sep.2005, P1733, Assiut university , Egypt.

8- Soretz,S.,Holzenbein,H.:Einfluss der Rippenabmessungen von Betonbe. wehrungsstaben auf den Verbund und die Biegefahigkeit. Betonstahl in Entwicklung.Tor-Isteg Steel Corporation. Luxenburg, Heft 69, 1980.

9- Aly A...El-Sayed et al "Effect of rib geometry for steel reinforcements on bond strength " Bulletin of the faculty of engineering, Vol. 29, J 2001, P1 , Assiut university, Egypt.

10- Ali M. Abdallah "Effect of rib geometry for steel reinforcements on bond characteristics and rotational capacity of exterior joints in structures" M.sc. thesis. Assiut University, 2000. 


\section{تأثير استخدام الألياف المعدنية والغير معد نية و هندسية التتوعات لأسياخ حديد التسليح}

\section{على مقاومة التماسك في الخربانة عالية المقاومة}

في الآونة الأخيرة ظهرت الحاجة لاستخدام الخرسانة عالية المقاومة و ذلك لاستخدامها في المنشآت ذات الارتفاعات العالية والمنشآت البحرية والمدنية العملاقة . و لذلك أصبح من الضروري استخدام حديد التسليح عالي الجودة و المقاومة وذي هندسية نتؤات مختلفة . للاستفادة من أقصى مقاومة لصلب التسليح في الخرسانة ذات المقاومة العالية فان الأمر يتطلب قوة تماسك كافية بين الحديد و الخرسانة مما يستلزم إن يحاط سطح حديد التسليح بنتوءات تكفل نولد قوى التماسك الكافية بينهما. ونظرا لان الخرسانة عالية المقاومة مادة قصفة وغير مطيلة لذا احتاجت الخلطة الخرسانية إلي بعض الألياف المختلفة وبالأخص الألياف المعدنية منل ألياف الهاركس و ألياف الحديد الملساء وكذلك الألياف الغير معدنية مثل ألياف الصوف الزجاجي وألياف البولي بروبلين و ذلك لتحويلها إلى مادة لها ممطولية معقولة.

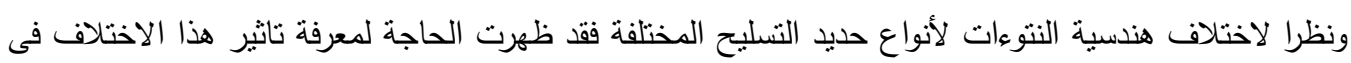
هندسية النتوءات و كذلك استخدام انواع مختلفة من الألياف وخاصة المعدنية والغير معدنية علي سلوك التماسك

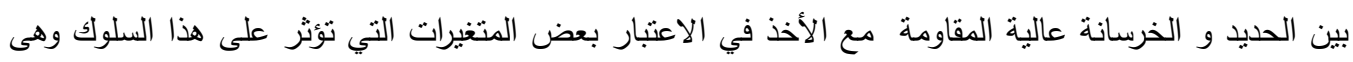
المساحة النسبية للنتؤ فى وجود تماسك جذئى لنهايات حديد النسليح..

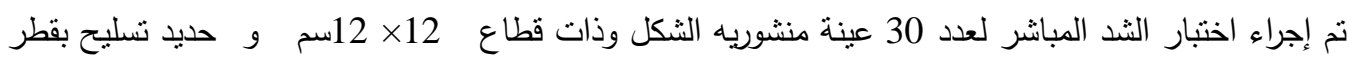
16 مم و كانت أطوال العينات المختبرة 15 مر ة قطر السيخ المستخدم و قد نم الآخذ في الاعتبار العوامل التالية :

1- هندسية النتؤات والمساحة النسبية للنتؤ لحديد التسليح المستخدم في عينات الاختبار وقيمها هي (0.0.

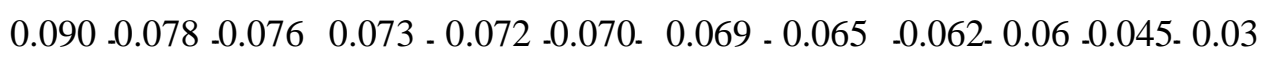
( 0.10 .

2- طول التماسك لأسياخ الحديد المستخدم في عينات الاختبار للثد المباشر و هي 5 مرات قطر السيخ

$$
\text { - المستخدم }
$$

3- تم استخدام نوع واحد من الخرسانة عالية المقاومة برتبة ( 900 كجم/سم2) •

4- نوع الألباف المستخدمة منها المعدنية مثل(ألباف الهاركس و ألياف الحديد العادي )وغير المعدنية مثل

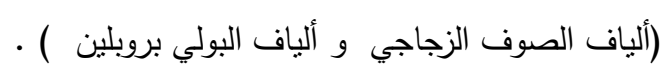

الهدف الرئيسي من هذه الدراسة هو محاولة الوقوف على تأثير استخدام الألباف المعدنية والغير معدنية و كذلك لكافي اختلاف هندسية النتوءات لأنواع حديد التسليح المشرشر المختلفة على خواص التماسك بين حديد التسليح و الخرسانة عالية المقاومة. وقد تم التوصل لنتائج هامة في هذا البحث - شكل الانهيار للخرسانة المسلحة عالية المقاومة ذات الألياف المعدنية يعنمد علي هندسية النتوءات

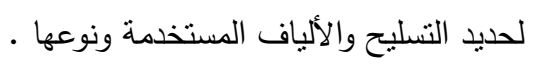

- - استخدام الألياف المعدنية يحسن من خواص الممطولية عند حدوث انهيار التماسك للخرسانة . 
- مقاومة الترابط تعتدد علي استخدام الالياف وتكون في حالة استخدام ألياف المعنية ذات قيم اعلى من حالة استخدام ألالياف الغير معدنية

- - قيم متوسط المقاومة القصوي في حالة استخدام الالياف اعلي من مثيلتها في حالة عدم استخدام

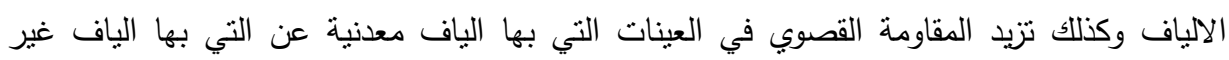

معدنية

- - القيم المتوسطة لمقاومة القصوى في حالة استخدام حديد مشرشرذو ننؤات ذات مساحة نسبية عالية

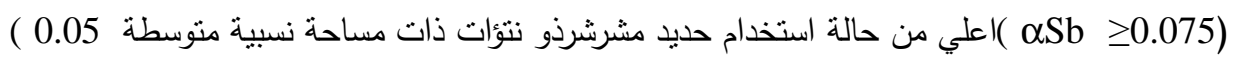

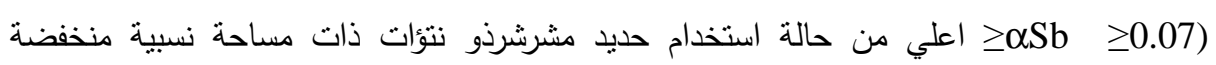

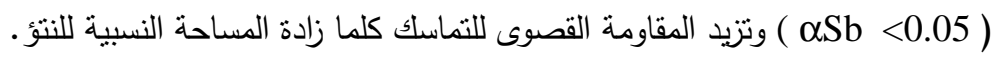

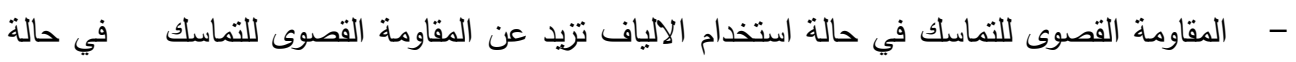

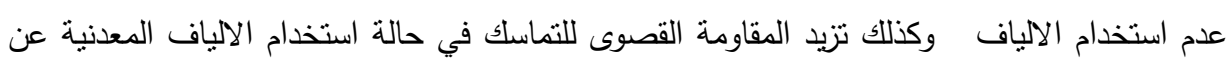
المقاومة القصوى للتماسك في حالة استخدام الالياف الغير معدنية

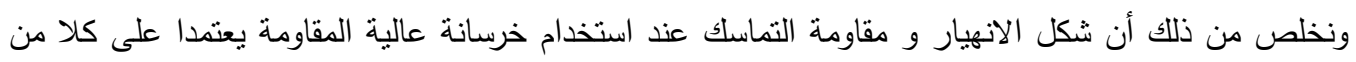

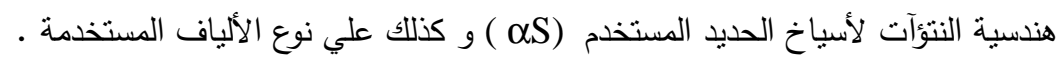

